\title{
Poesia portuguesa contemporânea: Portugal, 0 - Manuel de Freitas
}

Danilo Bueno $^{1}$

Recentemente, no Rio de Janeiro, uma pequena editora que elabora livros artesanais, publicou livros de poesia e de dramaturgia de autores contemporâneos portugueses. Trata-se da Oficina Raquel, http://www.oficinaraquel.com/, dirigida por Ricardo Pinto de Souza, poeta e doutorando da UFRJ (Universidade Federal do Rio de Janeiro). O projeto, intitulado Portugal, 0, foi idealizado para contemplar escritores portugueses que começaram a publicar no final da década de noventa e início dos anos 2000, demarcando a chamada geração 00 .

Tal selo é organizado e selecionado por Luis Maffei, poeta e professor da UFF (Universidade Federal Fluminense), que assina o excelente prefácio do volume inicial da coleção dedicada a Manuel de Freitas ${ }^{2}$. Até agora, foram lançados quatro títulos: três antologias de poesia - Manuel de Freitas, Rui Pires Cabral e Luís Quintais, respectivamente - e um volume dedicado ao teatro, com duas peças de Pedro Eiras. As edições de pequena tiragem, que podem ser encomendadas pelo endereço eletrônico da editora, chamam a atenção pelo labor artesanal e pela qualidade dos volumes em capa dura: trata-se de livros para durarem até antes do fim do mundo, como profetizam os colofones.

Tal iniciativa é muito bem-vinda, tendo em vista o quase completo desconhecimento do público brasileiro acerca da poesia produzida em Portugal nos dias de hoje. Além do óbvio caráter de divulgação, o projeto da Oficina Raquel impõe um paradigma a ser observado, pois demonstra como é possível a popularização da produção literária recente de determinada região sem que se espere a resposta oficial do mercado

\footnotetext{
${ }^{1}$ Danilo Bueno é mestrando em Letras - Literatura Portuguesa - na Universidade de São Paulo/USP.

${ }^{2}$ Conforme o site da editora: Manuel de Freitas nasceu em 1972, no Vale de Santarém. Vive desde 1990 em Lisboa, onde tem exercido as actividades de tradutor, crítico literário e editor. É co-director da revista Telhados de Vidro. Publicou, além de vários livros de poesia, ensaios sobre literatura portuguesa contemporânea e foi responsável, em 2002, pela organização da antologia Poetas sem Qualidades (Averno). Mais informações sobre o livro no link: http://www.oficinaraquel.com/manuel.html
} 
editorial, quase sempre assentada em fatores que excedem o texto literário, como a lógica que privilegia nomes consagrados e altamente comercializáveis.

É com satisfação, portanto, que se pode ler o volume inicial da coleção Portugal, 0 , que antologiza o poeta Manuel de Freitas. Nesse volume, vêem-se poemas que tonalizam uma visão cruel do mundo, do qual o poeta não pode passar ileso, como nos versos: "No urinol público lia-se UTILIZAÇÃO GRATUITA./ Fiquei quase feliz quantas coisas gratuitas/ há neste mundozinho de horror?)". Manuel escreve de forma clara e direta, sem floreios poéticos, rente à sensibilidade estranha e complexa da contemporaneidade.

Os temas dos poemas circulam pela morte, pelo amor, pelos bares, pelos amigos e pela literatura. Como se poderá ver, não há apego à originalidade temática, mas sim ao tratamento diferenciado de emblemas poéticos gastos. A poesia do cotidiano é problematizada, pondo em perspectiva o sujeito do poema, como exemplifica a série Isilda ou a nudez dos códigos de barras (FREITAS, 2007, pp.49-53), em que os títulos dos poemas são códigos de barras e a enunciação advém de uma caixa de supermercado que vê o mundo a partir do consumo. Não se trata de um sujeito poético literário, como fez Allen Ginsberg, ao saudar o célebre precursor Walt Whitman em um supermercado da Califórnia, (cf. GINSBERG, 2000, pp.48-49), mas sim de poetizar a fala de um enunciatário duplamente alijado: seja por ser mero mecanismo da superestrutura mercadológica; seja por ser privado das benesses do consumo, permanecendo inadaptado e atópico. $\mathrm{O}$ uso dos códigos de barras indica a debilitação no processo de nomear, cuja indeterminação aponta para a massificação e a reificação da vida. Há um paralelo entre a posição da caixa do supermercado e o poeta nos dias de hoje.

Sobre o tema da literatura, leia-se o perturbador poema Classificados: "O correlativo objectivo/ gastou-se, como era de esperar,/ e se a lírica sobrevive/ não me perguntes de quê, de que restos" (FREITAS, 2007: 64). Nestes versos, vê-se a desconsideração da teoria de T.S. Eliot sobre a associação da emoção ao objeto exato que a exprime, quebrando a correlação dialética entre mundo e linguagem. Manuel de Freitas se propõe exatamente em intensificar a distância dessa correlação a partir dos "restos" que o poema trata - relacionando a lírica a um sistema de lixo cultural. É uma forma 
revisionista de ler o cânone, sem reverência, selecionando apenas os pontos que podem fazer algum sentido para a escrita de hoje e também para o projeto pessoal do poeta.

Desde o prefácio feito por de Manuel de Freitas para a antologia Poetas sem qualidades (FREITAS (org.), 2002), que assume muitas vezes o tom de manifesto poético, a lírica portuguesa contemporânea tornou-se mais crua e incisiva, gerando novas questões para se pensar o fazer poético atual. O título dessa antologia faz referência ao livro do austríaco Robert Musil, O homem sem qualidades (cf. MUSIL, 1989), cuja tradução para o português trabalha com a ambigüidade da palavra "qualidade", conforme anotou Michael Hanke, "pois o termo qualidade designa, primeiro, ser de boa qualidade, e segundo, significa simplesmente propriedade sem conotação valorativa" (HANKE, 1998, p.1). Essa dupla leitura pode ser utilizada para essa tendência portuguesa e também para a poesia de Manuel de Freitas, que, simultaneamente, postula uma escrita sem as qualidades correntes (entenda-se qualidades correntes como o domínio de certa engenhosidade poética, livresca), e, em contrapartida, assume toda sua propriedade, definida no curioso bordão: "A um tempo sem qualidades, como aquele em que vivemos, seria no mínimo legítimo exigir poetas sem qualidades" (FREITAS (org.), 2002, p.9). Dessa forma, a escrita passa a se balizar por uma postura ético-crítica em oposição ao mundo vulgarizado e aculturado, o que inclui o mundo da literatura e os "puetas", conforme Manuel de Freitas escreveu ironicamente no aludido prefácio.

Essa proposição poética passa a se construir por veios axiológicos que minam a construção do mundo, caracterizando-se como uma estratégia de resistência e contestação, ao criar um parâmetro de politização lírica para a poesia portuguesa contemporânea, como uma espécie de segunda "volta ao real", mais ampla e mais desencantada do que a proposta por Joaquim Manuel Magalhães. Ou seja, não basta evitar a poesia que está submersa somente nos problemas da linguagem, mas também há que se pensar na configuração mesma do real, entre a existência de tantos reais: realvirtual, real-poético, real-crítico - conforme a observação de João Barrento de que hoje os poetas escreveriam diretamente para a recepção crítica (BARRENTO, 2006, pp.57-62) -; uma vez que a produção poética de hoje parece domesticada em estilemas esvaziados para a complexidade do mundo. É nessa conjuntura, nessa incisão na carnadura da realidade, que se inscreve, ao que parece, o interesse da poesia de Manuel de Freitas. 
Assim, a antologia Portugal, 0 - Manuel de Freitas empreende um lirismo saboroso, pois irônico e destruidor de plataformas poéticas. Uma poesia que se sabe linguagem, mas que duvida que essa linguagem seja válida se descolada de uma visada mais próxima do leitor, e, por conseguinte, da vida chã, do factível. Não se trata de realismo, mas de uma poesia que é intencionalmente simples (nunca simplista) para, logo após, subverter sua aparente facilidade, provocando relações ambíguas e desautorizadoras, que minam certos ideologemas, como o poema Spot: "O que, na verdade, me/ deixa saudades da censura,/ de uma censura nova/ que exterminasse imbecis/ e deixasse a terra a quem/ ela é, como deve ser, pesada. (FREITAS, 2007, p.55)”. Para Manuel de Freitas, a noção de qualidade é fundamental - qualidade essa construída pela autenticidade de uma visão particular do mundo.

\section{Referências Bibliográficas:}

BARRENTO, João. O Arco da palavra. São Paulo: Escrituras, 2006.

FREITAS, Manuel (org.). Poetas sem qualidades. Lisboa: Averno, 2002.

FREITAS, Manuel. Portugal, 0 - 1. Rio de Janeiro: Oficina Raquel, 2007.

GINSBERG, Allem. Uivo. São Paulo: LPM, 2000.

HANKE, Michael. A qualidade dos homens sem qualidades de Robert Musil. Disponível em: $<$ http://publique.rdc.puc-rio.br/revistaalceu/media/alceu_n8_Hanke.pdf $>$, acesso em 29/10/2008.

MUSIL, Robert. O homem sem qualidades. Rio de Janeiro: Nova Fronteira, 1989. 